\title{
EFEKTIFITAS IZIN ATASAN \\ DALAM PERCERAIAN APARATUR SIPIL NEGARA \\ DI WILAYAH HUKUM PENGADILAN AGAMA LIMBOTO
}

\author{
Nurhayati Hasan \& La Haji
}

ABSTRACT

Divorce of State Civil Apparatus (ASN) was regulated in accordance with the provisions of PP. 45 in 1990 who must obtain permission from superiors. This research discussed about the effectiveness of superior's permission to Divorce of Civil State Apparatus (ASN) and consideration factor by superiors in granting divorce permit for state Civil Apparatus (ASN) in Limboto Religious courts area.these research used descriptive qualitative method.types of data are sourced primary and secondary data by technique of collecting through depth interview as well as analysis of document case divorce.checking the validity of data is done through triangulation process.processing and data analysis done through data presentation, verivication, and conclusion.

The result showed that ASN superiors who applied for divorce were effective in minimizing ASN divorce in limboto religious courts area.the effectiveness of the regulation of ASN suvervisor's permission is shown by five indicators of legal effectiveness (read:regulation of the superior's permission) ASN,namely:(1) understanding of the divorce regulation of ASN divorce(2)socialization of ASN divorce supervisor's license (3)enforcement of regulation(4)level ofcommunity participation of ASN (5)creation of community life in the limboto religious courts area.

There are th of three indicators that indicators that get positive responses namely; (1) understanding of the superior's license,(2) socialization of the regulation of superior's,(3) the importance of the ASN divorce superior's liense to the creation of community lifestyle.the other aspects are: (1) law enforcement and (2) publick participation in realizing the licence of the superior divorce of ASN in the jurisdiction of limboto religious court area is stiil low.

The ASN superior's consideration factor in giving ASN divorce permit is because the parties have no desire improve the household relationship,change of faith, are not enough reason for divorce and to protect the child's life from negative effect because of bad communication relationship of parents.

As recommendation of this policy recommendation, this research is hoped that the religious courts and officials authorized give and refuse permission in order to combined the government regulation concerning marriage and divorce for civil servants can be maximized its enforcement.similarly to the officers of personnel development in the Gorontalo regency and north Gorontalo regency to optimize legal certainty and continuous monitoring infractions committed by ASN.

Keywords: The Effectiveness,superior's license,Divorce, Religious Court Area 


\section{A. Penduhuluan}

Idealnya sebuah Pernikahan adalah pernikahan abadi dunia akhirat. Ikrar yang terucap diantara dua insan manusia saat ijab-Qabul adalah ikrar atas pengakuan salah satu kemahabesaran Ciptaan-Nya. Sebab tujuan esensial inilah maka Undang-Undang Nomor 1 Tahun 1974 tentang Perkawinan mempersulit terjadinya perceraian. Asas mempersulit yang diemban Undang-Undang ini memandang suatu perkawinan sebaiknya tetap dipertahankan, Perceraian hanya dimungkinkan apabila tidak ada jalan lagi jalan untuk mendamaikan pasangan suami istri, atau dengan kata lain perceraian merupakan alternatif terakhir apabila sebuah rumah tangga tidak dapat lagi dipertahankan keutuhannya. Proses hukum perceraian ini terkandung dalam Pasal 39 ayat 1 Undang-Undang Tahun 1974 yang mengharuskan hakim didepan sidang Pengadilan untuk mendamaikan suami dan istri.

Asas mempersulit perceraian dengan melibatkan pengawasan pengadilan, apabila dibandingkan dengan prinsip hukum islam mengenai perceraian terdapat persamaan pandangan antara Undang-Undang Perkawinan dengan hukum Islam. Dalam Islam kendatipun perceraian merupakan sesuatu yang dibolehkan, akan tetapi perceraian tetap merupakan perbuatan yang tidak terpuji di mata Allah. Hal ini merupakan peringatan kepada umat manusia agar jangan terlalu menjatuhkan atau mempergunakan hak talaknya

Kesulitan yang dihadapi saat perceraian berhubungan erat dengan nilai kemuliaan yang dimiliki oleh pernikahan, bukankah Allah memulai kalamNya ketika menyinggung soal pernikahan dengan kalimat kesucian dalam ayat disebutkan : "Maha suci Allah yang telah menciptakan semua pasangan baik dari apa yang tumbuh dibumi, dan dari jenis mereka (manusia) maupun dari makhluk-makhluk yang tidak mereka ketahui ( Q.S Yaasin 36 : 36) ${ }^{1}$ Diantara tanda-tanda (kebesaran dan kekuasaan) Allah adalah Dia menciptakan dari jenismu

${ }^{1}$ Kementerian Agama RI , Al-Quran dan Terjemahnya, Penerbit Mahkota Surabaya tahun 2015. Hal. 235 
Jurnal Ilmiah Al-Jauhari (JIAJ)

Studi Islam dan Interdisipliner

Volume 3 No 2 September 2018

ISSN 2541-3430 E-ISSN 2541-3449

pasangan-pasangan agar kamu (masing-masing) memperoleh ketentraman dari (pasangan)-nya, dan dijadikannya diantara kamu mawaddah dan rahmah. Sesungguhnya yang demikian itu benarbenar terdapat tanda-tanda bagi kaum yang berpikir ( Q.S : Ar-Rum : 30 : 21). ${ }^{2}$ Menciptakan sebuah rumah tangga yang damai berdasarkan kasih sayang yang merupakan idaman bagi setiap pasangan suami isteri merupakan upaya yang tidak mudah, tidak sedikit pasangan suami isteri yang gagal dan berakhir dengan sebuah perceraian, Perceraian menjadi pilihan terakhir bagi pasangan suami istri setelah semua upaya telah ditempuh untuk menjaga keutuhan rumah tangga, hal ini terjadi pada masyarakat biasa atau dikalangan Pegawai Negeri Sipil atau yang disebut dengan Aparatur Sipil Negara.

Undang - Undang Aparatur Sipil Negara Nomor 5 Tahun 2014 Pasal 1 ayat 1 menjelaskan bahwa Aparatur Sipil Negara yang selanjutnya disingkat ASN adalah profesi bagi Pegawai Negeri Sipil dan pegawai Pemerintah dengan perjanjian kerja yang bekerja pada instansi pemerintah. Pada ayat 2 disebutkan bahwa Pegawai Aparatur Sipil Negara yang selanjutnya ASN adalah Pegawai Negeri Sipil dan Pegawai Pemerintah dengan perjanjian kerja yang diangkat oleh Pejabat Pembina Kepegawaian dan diserahi tugas dalam suatu jabatan pemerintahan atau diserahi tugas Negara lainnya dan digaji berdasarkan peraturan Perundang undangan, melihat kedua ayat dalam pasal tersebut maka Pegawai Negeri Sipil adalah unsur Aparatur Negara, Abdi Negara, dan Abdi Masyarakat yang harus menjadi teladan yang baik bagi masyarakat dalam tingkah laku, tindakan, dan ketaatan kepada peraturan perundang-undangan yang berlaku diantaranya Aparatur Sipil Negara harus memberikan contoh dan keteladanan kepada sesama Aparatur Sipil Negara, bawahannya, dan masyarakat. Sehubungan dengan hal ini maka Aparatur Sipil Negara dibebankan ketentuan disiplin yang tinggi. Dalam hal perceraian Aparatur Sipil Negara ketentuannya harus memperoleh Izin terlebih dahulu dari atasannya atau Pejabat yang berwenang. Amanat PP 45 tahun 1990 pejabat diwajibkan untuk melakukan pembinaan atau usaha untuk mendamaikan PNS yang berada dalam instansinya jika terjadi

\footnotetext{
${ }^{2}$ Ibid..hal. 432
} 
Jurnal Ilmiah Al-Jauhari (JIAJ)

Studi Islam dan Interdisipliner

Volume 3 No 2 September 2018

ISSN 2541-3430 E-ISSN 2541-3449

perceraian, hal tersebut dikarenakan PNS perlu mendapat izin dari pejabat sebelum bercerai. Selain amanah peraturan perundangan peran instansi dalam maslah perceraian diharapkan dapat membantu penyelesaian masalah pegawai tersebut, dikarenakan secara langsung atau tidak langsung kinerja dan produktiftas pegawai akan terganggu. Inilah sesunguhnya peran instansi untuk membantu menyelesaikan permasalahan. Dimana hal tersebut tertuang pada PP Nomor 53 tahun 2010 tentang Disiplin PNS, yaitu jika PNS tidak mendapatkan izin sebelum bercerai maka dapat dikenakan salah satu sanksi hukuman disiplin berat diantaranya Penurunan pangkat setingkat lebih rendah selama 3 (tiga) tahun.

1. Pemindahan dalam rangka penurunan jabatan setingkat lebih rendah.

2. Pembebasan dari jabatan bagi PNS yang menduduki jabatan struktural atau fungsional tertentu.

3. Pemberhentian dengan hormat tidak atas permintaan sendiri atau pemberhentian tidak dengan hormat sebagai PNS Ketentuan izin dimaksud karena

Pegawai Negeri Sipil merupakan tulang punggung pemerintahan dalam melaksanakan pembangunan nasional semua itu ditentukan oleh kedudukan dan peranan dari Pegawai Negeri Sipil tersebut. Semua perihal yang berkaitan dengan Pegawai Negeri Sipil di atur dalam perundang-undangan. Mengenai perceraian bagi Pegawai Negeri Sipil diatur pelaksanaannya dalam peratutan Pemerintah Nomor 10 Tahun 1983 tentang Izin Perkawinan dan Perceraian bagi Pegawai Negeri Sipil (PNS) yang kemudian diubah dan tambah dengan Peraturan Pemerintah Nomor 45 tahun 1990 Tentang Perubahan atas Peraturan Pemerintah Nomor 10 Tahun 1983 Tentang Izin Perkawinan dan Peceraian bagi Pegawai Negeri Sipil. ${ }^{3}$

(1) Pegawai Negeri Sipil yang akan melakukan perceraian wajib memperoleh izin atau surat keterangan lebih dahulu dari Pejabat;

(2) Bagi Pegawai Negeri Sipil yang berkedudukan sebagai penggugat atau bagi Pegawai Negeri Sipil yang berkedudukan sebagai tergugat untuk memperoleh izin atau surat keterangan sebagaimana dimaksud dalam ayat (1) Harus mengajukan permintaan secara tertulis;

\footnotetext{
${ }^{3}$ Pasal 3 Peraturan Pemerintah No. 45 Tahun
} 


\section{Jurnal IImiah AI-Jauhari (JIAJ) \\ Studi Islam dan Interdisipliner \\ Volume 3 No 2 September 2018 \\ ISSN 2541-3430 E-ISSN 2541-3449}

Pada 1990 tentang Perubahan Atas Peraturan Pemerintah Nomor 10 Tahun 1983 tentang Izin Perkawinan dan Perceraian bagi Pegawai Negeri Sipil ("PP 45/1990")'Dalam surat permintaan izin atau pemberitahuan adanya gugatan perceraian untuk mendapatkan surat keterangan harus dicantumkan alasan yang lengkap yang mendasarinya terjadi pada siapa saja tanpa batas ras, suku, agama, golongan dan batas wilayah. Kondisi Perceraian di Wilayah hukum Pengadilan Agama Limboto berdasarkan data yang berhasil dihimpun dari Pengadilan Agama Limboto menyebutkan bahwa Jumlah Perkara perceraian dalam lima tahun terakhir mengalami kenaikann cukup siginifikan hingga hingga tahun 2016. Rasio ini meningkat seiring dengan bertambahnya jumlah perkawinan di wilayah hukum Pengadilan Agama Limboto serta problematika sosial dan budaya masyarakat. Perceraian yang di putus dan telah berkekuatan hukum tetap di wilayah hukum pengadilan Agama Limboto 90 persen di sebabkan oleh faktor karena tidak ada keharmonisan dalam rumah tangga, faktor ketidakharmonisan ini sangat mendominasi alasan pengajuan perceraian oleh para pihak dalam lima tahun terakhir, sisanya karena krisis akhlak, tidak ada tanggungjawab, faktor ekonomi dan kekerasan jasmani.

Lalu bagaimana kondisi Perceraian di kalangan Abdi Negara (Baca ; ASN) di wilayah Hukum Pengadilan Agama Limboto? Data yang berhasil dihimpun dari sumber Resmi Pengadilan Agama Limboto meenunjukan bahwa jumlah ASN yang mengajukan perceraian meningkat secara siginifikan dari tahun ke tahun. Sepanjang tahun 2012- 2016 misalnya sebanyak 21- 45 kasus Perceraian atau rata-rata 9 persen dari total kasus perceraian di wilayah hukum Pengadilan Agama Limboto dilakukan oleh ASN. Jumlah Perkara perceraian ASN tertinggi yang di Putus dan telah berkekuatan Hukum Tetap serta memiliki terbit akta Cerai terjadi pada tahun 2013 dan 2014 masing-masing 42 (10 Persen) dari total jumlah perkara perceraian. Peningkatan jumlah perkara juga pernah terjadi antara tahun 2012- 2013 terjadi peningkatan hingga 100 persen atau 21 perkara perceraian ASN tahun 2012 menjadi 43 perkara perceraian ASN tahun 2013. (Lihat tabel 1.2) Dari Total tersebut sebagian besar (89 persen) memiliki Izin atasan sisanya 11 persen tidak memiliki Izin atasan. Pihak yang berperkara dalam kasus Perceraian adalah sebagian besar (42 persen) berasal dari kalangan Aparatur Sipil Negara dan didominasi Guru dan Pegawai Daerah.

Bagi ASN yang memiliki Izin atasan pada perkara perceraian sepanjang dalam lima tahun terakhir seluruhnya di dikabulkan dan telah berkekuatan hukum tetap, kecuali 1 perkara perceraian ASN yang telah memiliki Izin atasan namun telah dicabut perkaranya pada proses Persidangan. Bagi kalangan ASN yang mengajukan cerai tanpa Izin Atasan sebagian besar perkaranya telah di cabut (63,6 persen) sisanya 27,3 persen dikabulkan, perkara di Tolak tidak ada dan 9,1 persen dinyatakan gugur oleh Hakim. Perkara yang dicabut sebagian besar karena belum memperoleh izin dari atasan serta telah melakukan upaya damai sebelum izin atasan dikeluarkan. Jalan damai perceraian ASN disebabkan antara lain adanya pembinaan oleh atasan, adanya kesadaran para pihak untuk membina rumah tanggannya. Sedangkan perkara perceraian yang di tolak karena fakta persidangan menunjukan tidak adanya dalil kuat terhadap gugatan yang diajukan oleh penggugat / Pemohon. Dalil Pemohon/Penggugat umumnya mengajukan alasan sering terjadi pertengkaran dan tidak adanya keharmonisan, namun faktanya alasan 
Jurnal Ilmiah Al-Jauhari (JIAJ)

Studi Islam dan Interdisipliner

Volume 3 No 2 September 2018

ISSN 2541-3430 E-ISSN 2541-3449

Pemohon/penggugat tidak terbukti di persidangan. Alasan yang cenderung dimanipulatif menyebabkan permohonan perkara perceraian ini ditolak oleh hakim.

Berdasarkan data-data tersebut beragam faktor penyebab perceraian yang diajukan oleh masyarakat termasuk didalamnya Aparatur Sipil Negara yang sudah memenuhi ketentuan Aparatur Sipil Negara, akan tetapi ada Aparatur Sipil Negara mengajukan gugatan perceraian tidak memenuhi ketentuan sebagaimana yang telah diatur, dan gugatan tersebut dapat dikabulkan oleh Hakim Pengadilan Agama Limboto. Berdasarkan data spesifik tersebut, 


\section{B. Kajian Teori}

Kajian teori pada tesis ini di fokuskan pada hakikat efektifitas \& hakikat perceraian dalam konteks hukum serta ketentuan perceraian bagi kalangan Aparatur Sipil Negara (ASN). Soerjono Soekanto mengatakan bahwa efektif adalah taraf sejauh mana suatu kelompok dapat mencapai tujuannya. Hukum dapat dikatakan efektif jika terdapat dampak hukum yang positif, pada saat itu hukum mencapai sasarannya dalam membimbing ataupun merubah perilaku manusia sehingga menjadi perilaku hukum. Sehubungan dengan persoalan efektivitas hukum, pengidentikkan hukum tidak hanya dengan unsur paksaan eksternal namun juga dengan proses pengadilan. Ancaman paksaan pun merupakan unsur yang mutlak ada agar suatu kaidah dapat dikategorikan sebagai hukum, maka tentu saja unsur paksaan inipun erat kaitannya dengan efektif atau tidaknya suatu ketentuan atau aturan hukum. ${ }^{4}$

Efektivitas hukum berarti membicarakan daya kerja hukum itu dalam mengatur dan atau memaksa masyarakat untuk taat terhadap hukum. Hukum dapat efektif jikalau faktor-faktor yang mempengaruhi hukum tersebut dapat berfungsi dengan sebaik- baiknya. Ukuran efektif atau tidaknya suatu peraturan perundang- undangan yang berlaku dapat dilihat dari perilaku masyarakat. Suatu hukum atau peraturan perundang-undangan akan efektif apabila warga masyarakat berperilaku sesuai dengan yang diharapkan atau dikehendaki oleh atau peraturan perundang-undangan tersebut mencapai tujuan yang dikehendaki, maka efektivitas hukum atau peraturan perundang - undangan tersebut telah dicapai.

Teori efektivitas hukum menurut Soerjono Soekanto adalah bahwa efektif atau tidaknya suatu hukum ditentukan oleh 5 (lima) faktor, yaitu ; (1) Faktor hukumnya sendiri (undang-undang). (2) Faktor penegak hukum, yakni pihak-pihak yang membentuk maupun menerapkan hukum. (3) Faktor sarana atau fasilitas yang mendukung penegakan hukum. (4) Faktor masyarakat, yakni lingkungan dimana hukum tersebut berlaku atau diterapkan.dan (5) Faktor kebudayaan, yakni sebagai hasil karya, cipta dan rasa yang didasarkan pada karsa manusia di dalam pergaulan hidup. ${ }^{5}$

Teori efektivitas hukum yang dikemukakan Soerjono Soekanto tersebut relevan dengan teori yang dikemukakan oleh Romli Atmasasmita yaitu bahwa faktor-faktor yang menghambat efektivitas penegakan hukum tidak hanya terletak pada sikap mental aparatur penegak hukum (hakim, jaksa, polisi dan penasehat hukum) akan tetapi juga terletak pada faktor sosialisasi hukum yang sering diabaikan. ${ }^{6}$

${ }^{4}$ Soerjono Soekanto, Efektivitas Hukum dan Penerapan Sanksi, (Bandung : CV. Ramadja Karya, 1988), hal 80.

${ }^{5}$ Soerjono Soekanto, Faktor-Faktor yang Mempengaruhi Penegakan Hukum, (Jakarta : PT. Raja Grafindo Persada, 2008), hal. 8.

${ }^{6}$ Romli Atmasasmita, Reformasi Hukum, Hak Asasi Manusia \&Penegakan Hukum, (Bandung : Mandar Maju, 2001), hal. 55. 
Menurut Soerjono Soekanto ukuran efektivitas pada elemen pertama adalah : (1) Peraturan yang ada mengenai bidang-bidang kehidupan tertentu sudah cukup sistematis. (2) Peraturan yang ada mengenai bidang-bidang kehidupan tertentu sudah cukup sinkron, secara hierarki dan horizontal tidak ada pertentangan. (3) Secara kualitatif dan kuantitatif peraturanperaturan yang mengatur bidang-bidang kehidupan tertentu sudah mencukupi dan (4) Penerbitan peraturan-peraturan tertentu sudah sesuai dengan persyaratan yuridis yang ada. ${ }^{7}$ Berdasarkan uraian teori tersebut diatas, maka yang dimaksud dengan efektivitas pelaksanaan Izin atasan Perceraian ASN adalah tingkat kepatuhan ASN terhadap Peraturan Pemerintah Nomor 53 tahun 2010 tentang Disiplin PNS yang ditandai dengan : (1) Peraturan Izin Atasan terhadap Perceraian ASN mudah dipahami, (2) Peraturan tersebut diketahui oleh ASN, (3) aparat penegak hukum yang baik, (4) Partisipatif dan (5) Urgensinya Izin atasan Perceraian ASN terhadap bagi tatanan kehidupan masyarakat.

\section{Hakikat Perceraian}

Perceraian menurut hukum di Indonesia adalah yang tercantum dalam Undang-Undang Perkawinan No. 1 Tahun 1974, Peraturan Pemerintah No. 9 tahun 1975 tentang pelaksanaan UU No. 1 tahun 1974, Undang-undang No. 7 tahun 1989 tentang Peradilan Agama dan Instruksi Presiden No. 1 tahun 1991 tentang Kompilasi Hukum Islam. Ketentuan-ketentuan tersebut di atas secara umum disebutkan bahwa penyebab putusnya perkawinan dapat dikarenakan oleh tiga hal, yaitu kematian, perceraian, dan keputusan pengadilan. Pada pasal 39 Undang-undang No. 1 tahun 1974 disebutkan secara garis besar tentang tata cara perceraian, diantaranya : (a) Perceraian hanya dapat dilakukan di depan sidang Pengadilan setelah Pengadilan yang bersangkutan berusaha dan tidak berhasil mendamaikan kedua belah pihak. (b) Untuk melakukan perceraian harus ada cukup alasan bahwa suami istri itu tidak akan hidup rukun sebagai suami istri. Dan (c) Tata cara perceraian di depan sidang Pengadilan diatur dalam peraturan perundangan tersendiri

Ketika berbicara tentang perceraian maka kita tidak akan pernah lepas dari kata talaq karena secara harfiyah talaq itu berarti lepas dan bebas, dihubungkannya kata talaq dalam arti kata ini karena antara suami isteri sudah lepas hubungannya atau masing-masing sudah bebas. Menurut ulama fiqh suamilah yang mempunyai hak menjatuhkan talaq, bahkan suami sangat berkuasa dalam menjatuhkan talaq ia bisa menjatuhkan talaq kapanpun dia kehendaki, ketika ia menjatuhkan talaq dengan mengatakan "kamu saya talaq" maka jatuhlah talak kepada isteri yang berakibat putusnya hubungan suami isteri ${ }^{8}$ Tujuan dari perkawinan adalah terciptanya rumah tangga yang sakinah mawaddah dan warahmah, meskipun demikian bila hubungan pernikahan tersebut tidak dapat lagi dipertahankan dan kalau dilanjutkan juga akan menghadapi kehancuran dan kemudharatan maka Islam membuka pintu untuk terjadinya perceraian dengan demikian perceraian pada dasarnya dalam Islam adalah sesuatu yang tidak disenangi yang dalam istilah ushul fiqh disebut makruh. Hukum makruh ini dapat dilihat dari adanya usaha pencegahan terjadinya talaq itu dengan berbagai penahapan, memang tidak ada dalam Al-Quran ayat-ayat

\footnotetext{
${ }^{7}$ Soerjono Soekanto, Penegakan Hukum, (Bandung : Bina Cipta, 1983), hal. 80.
} 
yang menyuruh atau melarang eksistensi perceraian itu sedangkan untuk perkawinan ditemukan beberapa ayat yang menyuruh melakukannya.

"Bergaulah dengan Isterimu menurut patutnya, maka jika kamu benci padanya, janganlah bersegera menjatuhkan talaknya. Barangkali kamu membenci pada sesuatu perkara sedang Allah menjadikan kebajikan yang banyak di dalamnya (Q.S An- Nisa : 19$)^{8}$

Pengaturan khusus perceraian bagi Pegawai Negeri Sipil terdapat dalam PP Nomor 10 Tahun 1983 dan Peraturan Pemerintah No. 45 Tahun 1990 tentang perubahan atas Peraturan Pemerintah Nomor 10 Tahun 1983 tentang Izin Perkawinan dan Perceraian bagi Pegawai Negeri Sipil selanjunya disingkat PP No. 45 Tahun 1990. Oleh karena pertimbangan pengaturan hukum khusus bagi Pegawai Negeri Sipil dapat dipahami dari pertimbangan pemberlakuan kedua Peraturan Pemerintah tersebut.

${ }^{8}$ Tutuk Hamidah, Fiqh Perempuan Berwawasan Keadilan Gender, Malang: UINMaliki Press, 2011, h. 127. 
Jurnal Ilmiah Al-Jauhari (JIAJ)

Studi Islam dan Interdisipliner

Volume 3 No 2 September 2018

ISSN 2541-3430 E-ISSN 2541-3449

\section{Metode Penelitian}

Jenis penelitian dalam kajian ini adalah Kualitatif Deskriptif melalui pendekatan Studi hukum empiris terkait dengan Efektifitas Izin Atasan pada Perkara Perceraian dikalangan Aparatur Sipil Negara (ASN) di Wilayah Hukum Pengadilan Agama Limboto. Objek penelitian ini yang oleh Soekanto merupakan penelitian diagnostic, yang kemudian dilanjutkan dengan penelitian evaluative, jenis lainnya berupa pengaruh hukum positif terhadap kehidupan masyarakat, atau penelitian terhadap efektifitas hokum. ${ }^{9}$

Penelitian ini di fokuskan pada studi Efektifitas Izin Atasan pada Perkara Perceraian dikalangan Aparatur Sipil Negara (ASN) dengan lokus di Wilayah Hukum Pengadilan Agama Limboto dalam lima tahun terakhir yakni Tahun sidang tahun 2012 sampai dengan tahun 2016. Penelitian dilaksanakan mulai Bulan Desember 2017 s.d Februari 2018.

Teknik pengumpulan data dalam penelitian ini adalah dengan menggunakan Sumber Data Primer dan Sekunder. Data Primer adalah informasi /fakta pertimbangan hukum yang diperoleh dari Unsur Pengadilan Agama Limboto ; Hakim, Panitera dan pelaksana teknis, serta stakeholders Pengadilan Agama Limboto yang menangani Perkara Perceraian ASN di pengadilan Agama Limboto diantaranya BKD Diklat, Diknas dan Kementerian Agama

Teknik Pengolahan \&Analisis Data dilakukan melalui penyajian data (display data), dan penarikan verifikasi kesimpulan (concluction drawing). Menelaah seluruh data yang berhasil dikumpulkan yaitu dari

hasil wawancara, catatan lapangan (observasi), dan dokumentasi, selanjutnya peneliti mengadakan reduksi data, yaitu

merangkum, memilih hal-hal pokok, memfokuskan pada hal-hal yang penting, dicari tema dan strateginya dan membuang yang tidak perlu.Setelah data direduksi, maka peneliti menyajikan data. Penyajian data (display data) yang disajikan merupakan kumpulan informasi yang memberi adanya penarikan kesimpulan

\footnotetext{
${ }^{9}$ Soerjono Soekanto, Pengantar Penelitian Hukum. (Jakarta : UI Press, 1984) hal. 51 - 79
} 


\section{Hasil Penelitian}

Yurisdiksi Pengadilan Agama Limboto meliputi wilayah Kabupaten Gorontalo dan Kabupaten Gorontalo Utara. Kabupaten Gorontalo sendiri terdiri dari 19 Kecamatan yang terdiri dari 14 Kelurahan dan 194 dengan luas wilayah 2,125,47 $\mathrm{Km}^{2}$ dan Jumlah ASN 6221 ${ }^{11}$ sementara Kabupaten Gorontalo Utara terdiri dari 11 Kecamatan yang terdiri dari 134 Desa. Gorontalo Utara Jumlah ASN 2688 dengan Luas wilayah 1.777/02 Km ${ }^{210}$

Perkara dicabut di sebabkan oleh ; pada Pertimbangan hukum Putusan perkara No. 14/Pdt.G/2012/PA.Lbt dinyatakan bahwa Penggugat menyatakan akan mecabut perkaranya karena Penggugat telah rukun kembali dengan Tergugat, maka Majelis hakim menyatakan bahwa meskipun Tergugat hadir namun belum menyampaikan jawaban, atau pada saat persidangan belum memasuki tahap pemeriksaan pokok perkara, maka hak sepenuhnya kepada Penggugat untuk mencabut gugatannya tanpa persetujuan Tergugat sebagaimana pasal 271 alinea Pertama.

Sepanjang tahun 2012 sampai dengan 2016 perkara perceraian di pengadilan Agama Limboto yang mempunyai Izin atasan namun ditolak oleh Majelis Hakim sebanyak 4 perkara. Masing-masing pada tahun 2012 sebanyak 2 (dua) perkara sedangkan lainnya 2 (dua) perkara pada tahun 2013. Pemohon perkara berusia 29 - 47 tahun dengan latar belakang pekerjaan Guru dan Non Guru di wilayah Kabupaten Gorontalo (Lihat tabel 4.2)

Data yang berhasil dihimpun dari Pengadilan Agama Limboto tahun 2017 diperoleh bahwa sepanjang tahun 2012 hingga tahun 2016 terdapat 11 perkara Perceraian yang ditangani oleh Pengadilan Agama Limboto atau 6 (enam) persen dari total perkara perceraian ASN di wilayah hukum Pengadilan Agama Limboto 195 perkara perceraian ASN. Lebih dari separuh (63,6 persen) jenis perkara di cabut oleh Penggugat, 27,3 persen di Kabulkan oleh Majelis Hakim lainnya 9,1 persen atau 1 (satu) perkara Gugur, adapaun yang di tolak tidak ada. Perkara Perceraian tanpa Izin atasan yang di cabut di sebabkan oleh sebab hingga masa waktu 6 (enam) bulan tidak terbit Izin Atasan Penggugat sedangkan lainnya adalah pihak penggugat dan tergugat rukun kembali dalam rumah tangga. Adapun jumlah perkara perceraian yang dikabulkan oleh majelis Hakim Pengadilan Agama Limboto meskipun tidak memiliki Izin atasan adalah sebanyak 3 (tiga perkara, masing- masing dengan Nomor perkara :293/Pdt.G/2012/PA.Lbt, 131/Pdt.G/2015/PA.Lbt dan nomor perkara 276/Pdt.G/2016/PA.lbt perkara perceraian ini diajukan oleh ASN yang berprofesi sebagai Guru 1 (satu) orang dan 2 (dua) orang lainnya dilakukan oleh ASN pada sekretariat Daerah Kabupaten Gorontalo dan Gorontalo Utara.

Lebih dari 71 persen Penggugat perceraian dalam lima tahun terakhir (2012-2016) di Pengadilan Agama Limboto didominasi oleh perempuan hanya 29 persen Pemohon perceraian oleh lakilaki. Hampir separuh dari penggugat perceraian di Pengadilan Agama Limboto di di dominasi oleh penggugat yang berumur 31 - 40 tahun 48 persen, 23 persen berumur 41-50 tahun, 20 -30

${ }^{10}$ https://gorontaloutarakab.bps.go.id data di akses Tanggal 12 Februari 2018 pukul 20.00 Wita 
tahun 18 persen sedangkan hanya 11 persen 51-60 tahun. Pada seluruh kelompok usia ini di dominasi oleh perempuan. Lebih dari sepertiga penggugat perceraian di pengadilan Agama Limboto adalah berlatar Guru / pendidik ( Guru, Kepala sekolah, Dosen) namun 67 persen adalah Non Guru. Kalangan Non Guru ini berasal dari (ASN vertikal maupun pemerintah daerah). Lebih dari separuh 81 persen penggugat perceraian di wilayah hukum Pengadilan Agama Limboto berlatar belakang Pendidikan Sarjana (S1, S2, S3), Pendidikan SMA/sedarajat 19 persen. Data ini menunjukan bahwa tingkat pendidikan ASN yang mengajukan perkara cerai Talak atau cerai Gugat dilakukan oleh pihak-pihak yang mempunyai latar belakang pendidikan mumpuni. Kemapanan tingkat pendidikan ASN ini memungkinkan bahwa pengajuan perceraian ASN benar-benar dilakukan melalui pertimbangan matang berdasarkan alasan rasional.

\section{Efektifitas Izin Atasan terhadap Perceraian ASN di Wilayah Hukum Pengadilan Agama Limboto.}

Berdasarkan data yang berhasil di himpun menunjukan fakta bahwa terdapat beberapa hal yang mempengaruhi keberhasilan dan kegagalan dalam pelaksanaannya Salim ${ }^{14}$ menegaskan meliputi substansi hukum, struktur, dan kultur hukum. Substansi hukum yaitu peraturan yang akan ditegakkan harus jelas dan tidak menimbulkan multitafsir. Struktur hukum yaitu aparatnya menegakkan hukum secara konsisten. Kultur hukum yaitu masyarakat yang terkena hukum mendukungnya Sejalan dengan pemikiran di atas, Sabian Usman menyebutkan bahwa tiga pilar utama dalam penegakan hukum meliputi; Perundang-undangan atau substansi hukum yang akan ditegakkan, Aparat penegak hukumnya, dan kultur masyarakat tempat nilainilai hukum akan ditegakkan. ${ }^{15}$ Struktur hukum tidak akan berjalan dengan baik kalau tidak ditunjang oleh adanya substansi hukum yang baik pula. Demikian pula substansi hukum yang baik tidak akan dapat dirasakan manfaatnya kalau tidak ditunjang oleh struktur hukum yang baik. Struktur dan substansi hukum tidak akan dapat dirasakan eksistensinya kalau tidak didukung oleh budaya hukum masyarakat yang baik. Dengan kata lain, hukum akan berjalan efektif manakala ketiga aspek hukum di atas saling berinteraksi dan memainkan peran sesuai dengan fungsinya. Ibarat seekor ikan, ia akan hidup dengan baik manakala ditunjang oleh kualitas air kolam yang baik dan makanan yang baik pula. Apabia ketiga subsistem hukum tidak berfungsi dengan baik, maka akan muncul permasalahan dalam upaya mengimplementasikan hukum sebagai sarana pembangunan masyarakat itu sendiri.

\section{Sosialisasi Izin Atasan Perceraian ASN}

Sebagian kalangan menilai bahwa keharusan izin atasan bagi ASN yang hendak bercerai adalah bersifat kontroversial sebab muatan izin atasan dalam perkawinan dan perceraian bagi ASN tidak diatur dalam UU No 1 Tahun 1974 tentang Perkawinan juncto PP No 9 Tahun 1974 tentang Pelaksanaan Undang-Undang No 1 Tahun 1974 tentang Perkawinan. PP No 10 Tahun 1983 juncto PP No 45 Tahun 1990 yang mengatur tentang izin atasan bagi ASN bertentangan dengan undang-undang diatasnya. Sepatutnya PP sifatnya melaksanakan UU dan tidak membuat norma baru. Mengubah atau menambah aturan normatif dalam suatu perundangan harus dengan 
perundangan yang selevel: UU dengan UU, PP dengan PP Wilayah Hukum Pengadilan Agama Limboto.

Indikator penting mengenai efektifitas peraturan /hukum dalam masyarakat adalah luasnya penyebaran informasi bagi ASN terhadap syarat Izin pejabat yang berwewenang atas permohonan perceraian ASN. Hukum sebagai social engineering merupakan suatu sarana yang ditujukan untuk mengubah perilaku warga masyarakat agar sesuai dengan tujuan yang telah ditetapkan sebelumnya. Upaya menumbuhkan kesadaran ASN terhadap peraturan perceraian perlu dilakukan secara terus menerus dan berkesinambungan. Perubahan masyarakat termasuk ASN terhadap peraturan /hukum terjadi melalui rangkaian proses yang cukup panjang dan lama. Efektifitas Izin atasan bagi ASN yang melakukan perceraian juga akan ditunjang oleh upaya sosialisasi oleh kelembagaan baik dilingkungan Pemerintah daerah maupun bagi masyarakat luas. Dalam kerangka inilah Pengadilan Agama Limboto demi mewujudkan efektifitas dan optimalisasi pelayanan informasi pengadilan yang transparan, dilingkungan Pengadilan, melakukan pendayagunaan organisasi kelembagaan meliputi penataan struktur, fungsi, rentang kendali dan saling hubungan dalam proses pengambilan keputusan, penetapan kebijaksanaan alokasi dan realokasi sumber daya serta efisiensi birokrasi. Dengan demikian diharapkan akan mampu meningkatkan pelayanan publik yang optimal (Excellent Service).

\section{Penegakan Peraturan Izin Atasan}

Perceraian ASN di Wilayah Hukum Pengadilan Agama Limboto Achmad dalam bukunya Menguak Teori hukum (Legal Theory) dan Teori Peradilan (Judicialprudence) mengungkapkan bahwa efektifitas perundang -undangan atau suatu peraturan dapat ditinjau dari dua Perspektif yakni ; Persepektif organisatoris dan Perspektif Individu atau ketaatan. Dalam konteks ini, maka peraturan mengenai izin atasan terhadap perceraian ASN menunjukan adanya penegakan aturan secara institusional baik pada level pusat maupun daerah. Efektifitas izin secara institusional pada penelitian ini adalah terkait adanya ketaatan seluruh ASN di wilayah hukum Pengadilan Agama Limboto yang meliputi ASN di lingkungan pemerintah Daerah kabupaten Gorontalo dan Kabupaten Gorontalo Utara. Ketaatan institusional ini dilaksanakan secara menyeluruh tanpa kecuali, mulai dari pejabat /atasan ASN hingga ASN pada level terbawah (staf). Total ASN di Dua Wilayah hukum Pengadilan Agama Limboto ini berjumlah 7324 orang yang tersebar di 76 organisasi Perangkat Daerah (OPD) di 253 desa dan 43 Kecamatan.

Efektifitas izin atasan pada perkara ASN dalam perspektif individu adalah terkait tingkat ketaatan pribadi ASN yang menjalaninya. Faktanya ketaatan individual izin atasan ASN dalam perceraian cukup variatif, Terdapat ASN yang tingkat pendidikan dan pangkat lebih tinggi dari ASN lainnya, namun ketaatan terhadap peraturan rendah, sebaliknya ASN yang berpendidikan dan pangkat rendah namun ketaatan terhadap peraturan cukup baik. Dalam kaitan inilah perlunya sosialisasi dan kemitraan semua pihak dalam penegakan aturan perizinan ASN.

Penegakan hukum merupakan hal yang paling elementer dalam mewujudkan hukum yang berkeadilan bagi masyarakat, olehnya seluruh perangkat hukum secara totalitas mengabdikan semua kebijakannya untuk tegaknnya hukum. Penegakan hukum tidak memandang perbedaan suku, etnis, golongan apalagi sentiment agama. Ketidakpatuhan terhadap hukum dan peraturan yang menyertainya tidak saja mengacaukan sistem hukum tetapi merusak sendi-sendi kehidupan 
Jurnal Ilmiah Al-Jauhari (JIAJ)

Studi Islam dan Interdisipliner

Volume 3 No 2 September 2018

ISSN 2541-3430 E-ISSN 2541-3449

masyarakat. Oleh sebab itu dalam kerangka penegakan peraturan izin atasan bagi ASN yang mengajukan permohonan perceraian sepatutnya di patuhi oleh semua pihak. Tidak terkecuali pejabat dan pimpinan kepala daerah.Pemberian izin atasan tidak boleh bersifat diskriminatif apalagi sentiment terhadap orang/kelompok tertentu.Penegakan aturan yang benar dan konsisten sebagai adalah wujud pribadi ASN yang baik dan cerminan manusia yang bertaqwa. 
Jurnal Ilmiah Al-Jauhari (JIAJ)

Studi Islam dan Interdisipliner

Volume 3 No 2 September 2018

ISSN 2541-3430 E-ISSN 2541-3449

\section{E. Penutup}

Berdasarkan hal yang telah diuraikan maka diperoleh kesimpulan bahwa: Izin atasan cukup efektif dalam meminimalisir kasus perceraian ASN di wilayah Hukum Pengadilan Agama Limboto. Terdapat beberpa indikato yang mendapatkan respon lebih. Sehingga dapat disimpulkan bahwa penerapan izin atasan ini sangat efektif. 
Jurnal IImiah Al-Jauhari (JIAJ)

Studi Islam dan Interdisipliner

Volume 3 No 2 September 2018

ISSN 2541-3430 E-ISSN 2541-3449

\section{DAFTAR PUSTAKA}

Abdul Aziz Muhammad Azzam dan Abdul Wahab Soerjono Soekanto, Pengantar Penelitian Hukum.Jakarta : UI Press, 1984

Soerjono, Efektivitas Hukum dan Peranan Saksi, RemajanKarya Bandung, Indonesia

Soekanto , Fiqh Munakahat dan 1985. Undang-Undang Perkawinan,Jakarta:Kencana, 2009,

Sugiyono. 2012, Metode Penelitian Pendidikan Pendekatan Kuantitatif, Kualittatif, Dan R\&D, Bandung: Alfabeta.

Salam Moch. Faizal. 2003, Penyelesaian Sengketa Pegawai Negeri Sipil di Indonesia Menurut Undang-Undang Nomor 43 Tahun 1999, Bandung: Penerbit Mandar Maju.

Sastroatmodjo. Arso. 1981, Hukum Perkawinan Islam, Bulan Bintang: Jakarta.

Undang-Undang Nomor 1 Tahun 1974 Tentang Perkawinan Dan Kompilasi Hukum Islam. 2007, Bandung: PT. Citra Umbara. 